\title{
REDISCOVERING AMERICA: POLITICAL ECONOMY OF SPANISH COLONIES ACCORDING TO THE EXPLORERS JUAN-ULLOA, MALASPINA AND HUMBOLDT*
}

\author{
LUIS PERDICES DE BLAS AND \\ JOSÉ LUIS RAMOS-GOROSTIZA \\ Universidad Complutense de Madrid $^{\mathrm{a}}$
}

\begin{abstract}
Two scientists and sailors from the Spanish Navy, Jorge Juan and Antonio de Ulloa, the Italian sailor and explorer Alessandro Malaspina, and the German sage Alexander von Humboldt were the main actors in three great voyages to Spanish America between the second-third of the $18^{\text {th }}$ century and the beginning of the $19^{\text {th }}$ century. This enabled them to provide three first hand "photographs" of the state of the Spanish empire in America at three different moments in time: approximately before, during and after the implementation of colonial reforms designed in the reigns of Ferdinand VI and Charles III. This work aims, in the first place, to compare the socio-economic views of Spanish America deriving from the three expeditions, highlighting similarities and differences. Second, this work aims to connect the analysis of the weaknesses of the politico-institutional organisation of Spanish colonies, which the four travellers did at first hand, with the present debate on the role of colonial institutions in long-term economic development.
\end{abstract}

Keywords: Jorge Juan, Antonio de Ulloa, Alessandro Malaspina, Alexander von Humboldt, Spanish-American colonies

JEL Code: B11, B31

* Received 25 January 2015. Accepted 25 June 2015. We are very grateful to Barry Readman, the anonymous referees and the editors of the journal for their help and suggestions.

a Departamento de Historia e Instituciones Económicas I, Facultad de Ciencias Económicas y Empresariales, Universidad Complutense, Campus de Somosaguas, 28223 Pozuelo de Alarcón, Madrid, España.perdices@ccee.ucm.es; ramos@ccee.ucm.es. 


\section{RESUMEN}

Los científicos y marinos de la armada española Jorge Juan y Antonio de Ulloa, el marino y explorador italiano Alessandro Malaspina, y el sabio alemán Alexander von Humboldt, fueron protagonistas de tres grandes viajes a la América española realizados entre el segundo tercio del siglo XVIII y comienzos del XIX. Ello les permitió ofrecer tres «fotografías», de primera mano, de la situación económica del imperio español en América en tres momentos distintos: aproximadamente antes, durante y después de la puesta en práctica de las reformas coloniales diseñadas en los reinados Fernando VI y Carlos III. Este trabajo pretende, primero, comparar las visiones socioeconómicas de la América española derivadas de las tres expediciones, destacando convergencias y divergencias, y segundo, conectar el análisis de los problemas institucionales del imperio realizado por los cuatro viajeros con el debate actual sobre el papel de las instituciones coloniales en el desarrollo económico a largo plazo.

Palabras clave: Jorge Juan, Antonio de Ulloa, Alessandro Malaspina, Alexander von Humboldt, colonias hispanoamericanas

\section{INTRODUCTION: THREE VOYAGES TO SPANISH AMERICA, THREE COMPLEMENTARY VIEWS}

Scientists and sailors from the Spanish Navy Jorge Juan (1713-1773) and Antonio de Ulloa (1716-1795), the Italian sailor and explorer Alessandro Malaspina (1754-1809) and the German sage Alexander von Humboldt (17691859) were the main actors in three great voyages to Spanish America between the second-third of the $18^{\text {th }}$ century and the beginning of the $19^{\text {th }}$ century: in 1735-1745, 1789-1794 and 1803-1804, respectively. This enabled them to provide three first hand "photographs» of the state of the Spanish empire in America at three different moments in time: approximately before, during and after the implementation of colonial reforms designed in the reigns of Ferdinand VI and Charles III. In fact, the texts and materials stemming from their expeditions meant in a certain way a "rediscovery" of the socio-economic reality of the American colonies. Paradoxically, there was a significant ignorance concerning the matter since a large percentage of Spanish and foreign writers who dealt with economic questions related to Spanish America never set foot in this continent. Furthermore, although none of these travellers was an economist they all displayed excellent analytical ability and a clear interest in socio-economic matters, so that in the case of Malaspina and Humboldt their reading about this huge area was quite considerable. Moreover, even though they visited different areas of this vast American territory, which clearly shows the complementary nature of their respective analyses, they all attempted to reflect on the state of the Spanish empire as a whole. 
This work aims, in the first place, to compare the socio-economic views of Spanish America deriving from the three expeditions, with emphasis on convergence and divergence. Although there are many studies on the thought of Spanish economists, which inspired the Bourbon reforms or dealt with Spanish America, from Bernardo de Ulloa to Campomanes, passing through Campillo, Ward or Foronda, this has not been the case with some travellers who, unlike the economists, were in Spanish America and with more or less limitations, as will be seen later on, managed to devise a global diagnosis of the main problems of the empire ${ }^{1}$.

Specifically, we shall examine works which, although not the only ones written on their travels, were - however - those which most clearly emphasised the socio-economic aspects: Noticias secretas de América (Secret News from Spanish America) by Juan and Ulloa, written in 1747 and published in London in 1826 by David Barry; Axiomas políticos sobre la América (Political Axioms on Spanish America) by Malaspina, written in 1789, before his expedition and the various Descripciones y reflexiones politicas (Descriptions and Political Thoughts) which he subsequently produced following his Spanish-American experiences; and finally Ensayo político sobre el reino de la Nueva España (Political Essay on the Kingdom of New Spain) by Humboldt, originally published in French between 1808 and 1811.

Juan and Ulloa visited the Viceroyalty of Peru between 1735 and 1745, when the threat from England in the Pacific was already quite clear, the United States had not yet achieved independence, and the Bourbon reforms for America had not yet been put into practice. They were there as collaborators on an expedition of French scientists organised by the Académie des Sciences in Paris, which had the purpose of measuring the degree of the meridian of the Earth in the approaches to Ecuador ${ }^{2}$. The excursion was to give birth to the Noticias secretas de América, a confidential memoir on Spanish-American issues written in 1747 motu proprio by young sailors from the Spanish Navy Juan and Ulloa, who had no authority or experience in the subjects dealt with (though Antonio's father had been the mercantilist Bernardo de Ulloa), nor did they have - according to themselves - sufficient material to write it (Juan and de Ulloa 1985, I, p. 366). As well as revealing the «inexpert" view of Juan and Ulloa, the Noticias contained proposals in defence of private interests, such as those of the Jesuits, and show the ever-increasing interest which, since the first half of the $18^{\text {th }}$ century, awakened knowledge of political matters, and, especially, economic

${ }^{1}$ Two classical guides to what has been explained by the main $18^{\text {th }}$ century writers on Spanish America are Artola (1969) and Ezquerra (1962). For a more up-to-date synthesis, which concentrates on the economists, Perdices de Blas and Reeder (2003, pp. 188-194). On the reforms in Spain and its empire see Paquette (2008); and in particular, on the role of Campomanes in the measures taken during the reign of Charles III, see Llombart (1992, pp. 113-153).

2 On Antonio de Ulloa, Losada and Varela (1995) and Solano (1999); on Jorge Juan, Soler (2002). 
issues in Spanish territories on the other side of the Atlantic (Juan and de Ulloa 1985, I, p. 378).

Alessandro Malaspina was an Italian noble in the service of the Spanish Crown, trained in the Military Naval School of San Ferdinand (already renovated by Jorge Juan). He led a large politico-scientific expedition to the Spanish possessions in America and Asia at the beginning of the reign of Charles IV, between 1789 and 1794. This period was marked by the events of the French Revolution and when the reforms drawn up in the previous reign were still being put into practice. The expedition had a large team to carry out the scientific work (astronomers, botanists, geographers, painters, etc.), but there was also an attempt to discover the "sources of public wealth», by analysing questions such as trade between Spain and its American colonies, their administrative systems or possible conflicts with other powers. Before commencing the voyage Malaspina had already acquired a fairly accurate idea of the socio-economic state of the Empire thanks to his wide perusal of many different writers ${ }^{3}$. This produced the already cited Axiomas, a short, clear, synthetic work, not published in his lifetime, which condensed his view of the fundamental problems of the Spanish Empire, and which the Descripciones - written in sight of the effective reality of the viceroyalties - simply corroborated with details.

Finally, the multifaceted Humboldt - who, amongst other things, was a geographer, naturalist, explorer and humanist - visited between 1803 and 1804 the Viceroyalty of New Spain, which at that time corresponded to what nowadays is Mexico, the southeast of the United States and part of Central America. Before, between 1799 and 1803, he had also travelled in other parts of Spain's American Empire - Venezuela, Peru, Ecuador, Colombia and Cuba - and later on, he would go to the United States via Havana. However, it was in New Spain that his attention centred specifically on the «sources of public wealth». Humboldt visited the Viceroyalty at a time when the improvements linked to Bourbon reforms were palpable. Nonetheless, paradoxically, when he published his Ensayo politico sobre la Nueva España between 1808 and 1811, with Spain occupied by Napoleon's armies, the long and complex process of the independence of Spanish America had begun to make progress in an unstoppable fashion. With the backing of Charles IV to whom the work is dedicated - he had free access to a large number of data and documents, even confidential ones, and also he had the presence of many bureaucrats, learned individuals and men of science from the

3 They included historians of the colonisation of America (such as the abate Raynal or Robertson), important Italian economic policy experts (such as Galiani, Genovesi or Filanggieri), great references from the Scottish Enlightenment (such as Hume or Smith), those espousing new American thought (such as Jefferson), renowned voyagers (such as the above-mentioned Jorge Juan and Antonio de Ulloa), and - especially - a long series of Spanish $18^{\text {th }}$ century economists and politicians (such as Uztáriz, Campillo, Bernardo de Ulloa, Gándara, Ward, Olavide, Campomanes, Gálvez, Aranda, Cabarrús, Villaba, Floridablanca or Romá y Rosell). See Vericat (1994) and Pimentel (1998, pp. 117-139). 
Viceroyalty and Spain. In writing the Ensayo he no doubt had useful knowledge acquired in the Handelsakademie in Hamburg and the Mining School in Freiburg, his experience as an employee of the Prussian Administration, and his travels through Switzerland, Holland, Italy, England and France. In addition, his intellectual sources were widespread ${ }^{4}$.

Second, this work aims to connect the analysis of the weaknesses of the politico-institutional organisation of Spanish colonies, which the four travellers did at first hand, with the present debate on the role of colonial institutions in long-term economic development. Specifically, we will focus attention upon the contributions of Engerman and Sokoloff (1997), Acemoglu et al. $(2001,2002)$ or Hough and Grier (2015), who have emphasised the persistence in Latin America of unfavourable institutional models that dated from the colonial era, and led to lower long-term economic development compared with the United States. The aim is to see how unfavourable colonial institutions which these modern writers have highlighted had already been identified at that time by the four travellers (e.g. extractive institutions as trade monopolies and abusive taxes, heavy concentration of wealth, human capital and power in the hands of a few, or little effective political centralisation and clear backwardness in creating the efficient bureaucracy of a modern State). Moreover, the purpose is to see how the Bourbon reforms - especially in the light of what Humboldt said — involved certain improvements which had not yet had time to be established.

In fact it was Adam Smith who launched the debate that nowadays has been taken up by economists and economic historians such as North, Acemoglu and Engerman. He had already established that the English colonies in North America had undergone a faster economic development than the Portuguese, French and Spanish colonies as a consequence of institutions more favourable to improving and cultivating the land. In comparative terms and in present day language, the English colonial system, with all its many defects, was less extractive. That is, albeit the English institutions were bad the others were even worse. Thus, for example, English colonial trade was monopolistic but «a less illiberal and oppressive» (Smith 1987, II, pp. 613, 631).

For Acemoglu et al. $(2001,2002)$ the fact that those areas which were relatively wealthy in 1500 - like the civilisations of Mesoamerica and the Andes - nowadays are relatively poor compared to North America, Australia and New Zealand (which, nevertheless, were poor 500 years ago), would be explained by the different institutions established by European colonialism in

${ }^{4}$ He was familiar with German cameralist literature (Kameralwissenschaft), but he was particularly a great admirer of Adam Smith and showed his awareness of authors such as Malthus, Germain Garnier - translator of Smith and follower of Quesnay - Necker, Raynal, Robertson or Jefferson, among others. As for the Spanish sources of the Ensayo, they were very extensive, spreading from the first journalists missionaries and travellers of the $16^{\text {th }}$ century to some member of the latter period of the Enlightenment. See Annex 2 of the introductory study by Ortega y Medina (1991, pp. CXXII-CXLII). On the political thought of Humboldt, see Brann (1954). 
each case in accordance with local conditions. For example, in the already densely populated areas where it was often difficult to establish colonies due to the high death rate caused by diseases such as malaria or yellow fever, Europeans tended to introduce extractive institutions to force the native population to work in mines and plantations. On the contrary, in areas which were scarcely populated and where physico-climatic conditions were favourable for establishing colonies (since they did not produce a high death rate), the Europeans settled there in large numbers and created replicas of their own countries of origin, fomenting institutions to guarantee law and order, protect property rights, and promote trade and manufacturing, which already in the $19^{\text {th }}$ century would enable to make the most of industrialisation opportunities.

Moreover, Engerman and Sokoloff (1997) have underlined the strong inequality of wealth, human capital and political power which was characteristic of colonial South America as an explanation of its subsequent backwardness compared to North America. Such extreme inequality was related both with the suitability of some Iberian American regions for the cultivation of sugar and other high value produce which used slave or forced labour, and the presence of a large native population. Both aspects would have favoured a small elite of descendants of Europeans grabbing a disproportionate amount of wealth, human capital and power, establishing their political and economic power over the vast majority of the population. In turn, this great inequality would have had a negative economic effect not so much for its impact in capital accumulation rates, but rather for its effect on the evolution of markets and technical change.

Finally, Hough and Grier (2015) - starting from North, Olson and Weber consider that the key to the slow economic growth of Spain and her colonies lay in the weak de facto political centralisation and the backwardness - compared to England - in creating the efficient bureaucracy, which characterises a modern State. For these writers the construction of a modern State - with its professional and specialised bureaucracy and impersonal rules (replacing personal favouritism, arbitrary taxes, monopoly privileges, strong weight of family ties, etc.) - is an historic process that is very long and complex, but nonetheless indispensable in the full development of markets. However, in the opinion of these writers, whereas England had managed to build up a minimally effective State at the beginning of the $18^{\text {th }}$ century, Spain had scarcely begun to construct one with the Bourbon dynasty at the end of that same century.

\section{THE TRAVELLERS LOOK AT THE SOCIO-ECONOMIC REALITY OF SPANISH AMERICA: IDENTIFYING INSTITUTIONAL PROBLEMS}

\subsection{Jorge Juan and Antonio de Ulloa}

In his Noticias, written before the beginning of the reforms carried out during the reigns of Ferdinand VI and Charles III, Juan and Ulloa made some 
exaggerated, inaccurate criticisms and proposed measures that often betrayed a lack of reflection and coherence ${ }^{5}$. However, they already detected institutional problems in the Spanish colonial system, which essentially correspond to those cited nowadays by scholars of the role of colonial institutions in long-term development. Moreover, in line with Acemoglu et al. $(2001,2002)$ they transmitted the strongly extractive nature of the institutions of the Viceroyalty of Peru, which in turn was reflected in three aspects.

First, it showed itself in the obsession with precious metals, while a large amount of natural resources were left unexploited, and totally unused. The huge mineral wealth of the Viceroyalty was not only limited to precious metals (their mines of which were not properly exploited or in some cases not exploited at all), but it extended to iron, copper and semi-precious stones - such as quartz or lapis lazuli - or precious ones - such as emeralds. There was also the chance to commercialise saltpetre, salt, sulphur or cope, a species of polish used by sailors on their boats (Juan and de Ulloa 1985, II, pp. 445-449). As far as the plant kingdom was concerned, there was a great abundance of different resins and other products of industrial use, as well as cinnamon, pepper and medicinal plants. Moreover, in the animal world in particular, there was coral, cochineal and vicuna wool, which made possible the manufacture of fine headwear at competitive prices ${ }^{6}$. In any case, the conclusion was obvious: Spaniards had not taken commercial advantage of the raw materials in her colonies; they had only opted for precious metals and, paradoxically, had been forced to hand over these precious metals to foreigners in exchange for raw materials they had an abundance of in their American territories. What is more, France and - particularly - England, with no mines for precious metals, had become rich through the trade in common raw materials (Juan and de Ulloa 1985, II, p. 499). In this sense, in the Noticias there was confirmation of the conclusions of Castilian arbitristas in the $17^{\text {th }}$ century: the mines of precious metals had not enriched Spaniards ${ }^{7}$.

\footnotetext{
5 We are not going to give an evaluation of the measures proposed by the two sailors, but we will highlight that some of the most important, particularly those involving significant changes, would have had to be more thought out and more streamlined. For example, his proposal to reduce illegal trading never questioned the colonial monopoly (Juan and de Ulloa 1985, II, pp. 119-145), whereas his attitude towards the mita was equivocal. Thus, strongly did he criticize the mita that early on, they were in no doubt about proposing its abolition and that the wages of the Indians should be set by the market: "With no mita and if they were free to sell their labour that was available, they would be willing to work» (Juan and de Ulloa 1985, II, p. 233). Nonetheless, to prevent protests from landowners they finally proposed maintaining the mita and some reforms full of good intentions, such as the need to improve the economic conditions of the Indians and the banning of physical punishment.

6 In general Juan and Ulloa did not opt for the construction of factories in the colonies, but, rather for the strengthening of the trade in raw materials (Juan and de Ulloa 1985, II, p. 499). They also rejected the introduction of vicuna breeding in the Iberian Peninsula, because this could be extended to the rest of Europe and harm Spanish commercial interests (Juan and de Ulloa 1985, II, p. 494).

7 On arbitrist thought on this point, see Perdices de Blas (1996, Ch. 2).
} 
Second, another of the aspects in which the extractive nature of the institutional framework had its reflection was that it favoured corruption and the get-rich-quick culture of a few - both Spanish Europeans and Creoles, whether lay people or ecclesiastics - prejudicing the majority of the Indian population, of the Royal Treasury and of productive activities ${ }^{8}$. A concrete case: in the administration of justice and the internal organisation of government, public servants did not attend to «any other interests but their own private ones» (Juan and de Ulloa 1985, II, p. 29). Magistrates and judges were supposed to be obliged to enforce the law in order to «restrain vices which are to be found in the nature of men», but the reality was that their actions had led to «despotism» being the order of the day in Peru (Juan and de Ulloa 1985, II, p. 367). Those who had executive or judicial power, as well as their relatives, were only interested in making as much money as possible out of their posts. In fact, «in Peru people played freely with justice» (Juan and de Ulloa 1985, II, p. 387). The origin of all this was public servants, who in the Iberian Peninsula were happy to be paid «enough to be decent in their job», when transferred to America thought they had to obtain a growing stack of money in a short time (Juan and de Ulloa 1985, II, p. 391). However, not only was the behaviour of civil servants fit to be punished by law, even in the case of the clergy (except for the Jesuits) they wanted to make a quick fortune, lived licentiously and went so far as to practice polygamy (Juan and de Ulloa 1985, II, p. 435).

This discretional behaviour on the part of civil servants and the getrich-quick culture led to disruption in the workings of the tertiary sector (mainly commerce) and the primary (agriculture and mining). Commercial practices were upset because governors and ministers in the courts did not act lawfully since the law did not permit them to take part in such activities and they really became "professional traders" (Juan and de Ulloa 1985, II, p. 384). In addition, these public servants protected illegal trading and derived profit from it (Juan and de Ulloa 1985, II, p. 119) ${ }^{9}$. This illegal trading - from which no port, city or town escaped - broke the law, cheated the tax authorities and, naturally, allowed to benefit some public servants without "honour», who were also rewarded with «bloated salaries» by the king

${ }^{8}$ Let us put to one side the conflict between Creoles, which was later analysed by Malaspina, because what interests us is to highlight that both groups behaved similarly when they held public office, and this distorts the working of economic activities. Ramos, editor of the work of Juan and Ulloa, made the point that this conflict was in fact the conflict existing in a society that tended «to monopoly and to grabbing in all areas» (Juan and de Ulloa 1985, I, p. 63). Moreover, it is worth stressing that the two sailors blamed, on the one hand, the Creoles - particularly those living in the sierra - of abandoning commercial activities and treating newly arrived Spaniards from the Iberian Peninsula like nobles, even when they were poor plebs; and, on the other, Peninsula Spaniards, devoid of merit, grabbing public posts and commercial activities that the Creoles had left (Juan and de Ulloa 1985, II, pp. 336-338).

9 This illicit trading had already been denounced insistently by Bernardo de Ulloa (1992, pp. 205-230). 
(Juan and de Ulloa 1985, II, p. 137). Smugglers, on the other hand, were pardoned by Juan and Ulloa, «because as the same people who should close the doors to them opened then instead, they took advantage of the opportunity to make an extra profit on their trade» (Juan and de Ulloa 1985, II, p. 134).

Third, the extractive nature of the industrial framework left its mark, especially when it came to exploiting the Indian workforce in the primary sector (since in the Viceroyalty of Peru few African slaves were imported). This exploitation had been attacked by Bartolomé de las Casas and many other writers since the early years of the Conquest, but - according to Juan and Ulloa - in 1747 the exploitation was so harsh that many Indians died at their places of work thus decimating the workforce and removing any stimulus to work in any productive activity. Denouncing the extensive mistreatment of the Indians - which even made the situation of African slaves appear benign - was in fact one of the crucial points made in the Noticias. For example, it was pointed out that the Indians were made to pay taxes from which they were exempt as youngsters or the old, and the fruit of this excess stayed in the pockets of the public servants (Juan and de Ulloa 1985, II, p. 157). They were also cheated by repartimientos that were set up so that the judges could supply the Indians with basic goods at moderate prices. However, the only shops allowed to open were controlled by the mayors, who against what was legally stipulated cared only to gain the maximum profit from their use by selling goods at extortionate prices (Juan and de Ulloa 1985, II, p. 170). The Indians were also exploited by the religious - except the Jesuits - who should have gone further to put a stop to the abuses of civil authorities. On the other hand, they arrived in Spanish America with the aim of "making a fortune» in mind, and obliged the Indians to practice almsgiving, thus depriving them of what they needed to keep body and soul together (Juan and de Ulloa 1985, II, pp. 186-187). Indeed, the religious with their relaxed ideas and their keenness to lay hands on the small amount of economic resources of their followers, were setting a bad example and breaking with everything preached on Christian charity.

However, the Indians were not just cheated by civil and religious authorities, but also by the encomenderos and the system of forced labour known as mita. This left the Indians trapped in the network of ranch owners by the compulsory work they had to carry out under the mita system and by what they had to do to pay off their debts, which had partly been run up from the previously mentioned extortions that they suffered from the public servants and the religious ${ }^{10}$. The description given by Juan and Ulloa of the tough jobs

${ }^{10}$ The Indians were not only swindled by excessive, illegal taxation or paying alms, but also their lands were taken away from them. The problem arose because the Indians had no legal title to their land except their previous possession of it; or they were swindled, or used violence to keep their property. In addition, the Indians were often accused of being irresponsible in selling their properties without considering that in future sales they could be completely unprotected legally (Juan and de Ulloa 1985, II, p. 247). The Indians were the losers who saw themselves forced into voluntary mita, 
carried out by the Indians, which sometimes led to their deaths, could not be more heartrending:

«[Many Indians] died on the same work with their jobs in their hands, because even if they felt ill and looked ill, it is not enough to lead those tyrants to spare them from work or to try to cure them before» (Juan and de Ulloa 1985, II, p. 221).

Juan and Ulloa rejected the argument that without the mita the Indians would not work because they were lazy by nature: they did not deny that the Indians were phlegmatic and slow, and that it was a very hard task to "get them to work», but they wondered who would be induced to work in those conditions. What is more, «if in Spain they imposed a regime in which the wealthy forced the poor to work for their benefit completely unpaid, what incentive would [the latter] have to do so?». And in case that was not clear, the coup de grace:

"Are the rules of government and economics of those countries instituted so badly for the Indians that, if the income that is earned by these people is the same if they work or if they don't, shouldn't we be surprised that their weakness inclines more towards idleness than that of laboring, this being the natural order of things. So if we study the most cultured nations in the world, we won't discover, among all of them, one nation who sets out to work, lacking any incentive to improve his situation, and even countries that we see to be the most hard-working are those who are most stimulated by usefulness» (Juan and de Ulloa 1985, II, p. 227).

Similarly, the irrefutable proof that Indians were not so idle lay in the bridges, pavements, roads, temples and other works found by Spaniards when they first set foot in Spanish America. Moreover, the mita was also a hindrance to public revenue, because deaths of Indians and their unwillingness to work were reflected in the fall in the number of taxpayers and the tax take (Juan and de Ulloa 1985, II, p. 229). Jorge Juan and Antonio de Ulla concluded their analysis on the exploitation suffered by the Indians stating that this explained why there were many of them who had no wish to be part of the colonial system and had a deep contempt for Catholicism, preferring to flee "from the comforts of rationality, [and] not to approach the gates of slavery» (Juan and de Ulloa 1985, II, p. 281).

(footnote continued)

and the winners the buyers who increased their possessions and gained access to a workforce signed on at minimum wages. 
Furthermore, all that has been described above by Juan and Ulloa provides a clear overview of extreme social inequality and concentration of power and wealth among just a few elites, as mentioned by Engerman and Sokoloff (1997), with the too well-known negative results on the possibilities of long-term economic growth. That is, the great majority of the native population of the Viceroyalty of Peru, bereft of property and stripped of civil rights, lived at the mercy of a small elite, being exploited in different ways (the forced labour of the mita, abusive taxation, etc.).

Finally, Juan and Ulloa provide us with information which refers to the main institutional problems pointed out by Hough and Grier (2015): the lack of sufficient centralisation and an effective State. On the one hand, Juan and Ulloa underlined the clear difficulty existing in trying to rule and supervise such distant territories from Spain, which made for a degree of discretionary behaviour and an excess of autonomy granted to public servants in the Viceroyalty. On the other, Juan and Ulloa particularly stressed that the State did not fulfil its three basic functions there, of fomenting economic growth, as Adam Smith would define it in $1776^{11}$. This meant the State was unable adequately to defend the colonies from their enemies, it had not set up proper systems of government and justice - as has already been mentioned - nor had it constructed the minimum infrastructures to favour home and maritime trade. Juan and Ulloa particularly highlighted the fact that by not providing sufficient means to defend the American territories the Spanish colonies lived in a constant state of alarm in face of the threat of being captured by foreign powers, and therefore there was distortion in the normal working of its economic system. The military squares both in the Pacific (Guayaquil, Callao and Valparaiso) and the Atlantic ones (Cartagena and Portobello), so essential for trade, lacked sufficient defence (Juan and de Ulloa 1985, II, pp. 33-36, 520). This would also be aggravated because the situation of the Navy in Spanish America was precarious. There was a lack of good shipyards, the arsenals were very badly administered, there were no good armouries, the Navy Corps and the hospitals were badly organised, and the state of the ships was inadequate (Juan and de Ulloa 1985, II, pp. 579, 589, 597-606, 609-628, 642). These conditions made it difficult to fend off the aggressive forays of foreign powers, particularly from France and England.

11 On the minimum functions of the State, see Smith (1987, II, pp. 724-843). The Scotsman was a man of few words when revealing the sources of his thoughts, but he cited Juan and Ulloa in The Wealth of Nations, when he referred to the Spanish-American colonies. Clearly he did not quote the Noticias, which was not edited till 1826, but he did so with the Relación Histórica del viaje a la America Meridional de orden de S.M. para medir algunos grados del meridiano terrestre (Historical description of the voyage to South America carried out on orders from His Majesty to measure some degrees of the meridian), published in 1748 and translated into French in 1752. See Smith (1987, I, pp. 227, 248-249, 266, 283; II, pp. 609, 617). See also Newland and Waissbein (1984). 


\subsection{Alessandro Malaspina}

Malaspina, unlike Juan and Ulloa, was given the task of informing about the socio-economic state of the colonies. Moreover, he was better trained in these matters, he was up-to-date on the results of the measures of reform taken during the reigns of Ferdinand VI and Charles III, he prepared a plan for America before sailing, and clearly saw the greater threat of the European powers in the Pacific, an ocean which had been practically reserved for Spain till the $18^{\text {th }}$ century. Though he shared with Juan and Ulloa the idea of banning smuggling and criticised the hard work conditions of the Indians (Malaspina 1991, pp. 156-160, 184), he differed from them in three important aspects, criticising the inefficient monopolist and protectionist trade system which was quite mercantilist, valuing the role that could be played by the parish priests - more than the high-ups of the Church, the military and politicians - when uniting the empire ${ }^{12}$, and proposing a global reform to include the European, Asian and American territories of Spanish empire. In this last point Juan and Ulloa only put forward partial measures, which have been mentioned in the previous section.

Malaspina's writings on political economy were based on solid doctrine and were the fruit of theoretical thought, not improvisation like those of Juan and Ulloa. Even though the latter detected the three basic functions which the State did not cover, Malaspina was the one who made a more profound analysis of the bad definition of the political-economic system (which today is called institutional framework) and excessive State intervention in economic affairs. There was no contradiction between what was said previous to the voyage in the Axiomas and what is recorded in the memoirs on politico-economic affairs after it, although in the latter certain qualifications were inserted. As de la Sota (1994, p. 15) points out, after the expedition Malaspina simply adapted the reforms suggested in his Axiomas from 1789 "to the personality of each territory» ${ }^{13}$. Therefore, we will center on them, because they were the essence of his thought and - according to the author himself — they expressed his ideas in the form of simple principles, purged of prejudices and false praise, taking reality just as he found it and not as it should be ${ }^{14}$.

12 See the second axiom: «The preservation of America is rather the effect of the system of religion than the military and political ones» (Malaspina 1991, pp. 153-155).

13 In volume VII of the works of Malaspina (1995), all his political-economic memoirs on the main places visited during the expedition are recorded. This covers the area from Río de la Plata to Australia, passing through California, the Philippines and the Mariana Islands. Pimentel (1998, p. 376) affirms that the expedition served Malaspina in confirming the truth of his hypotheses and axioms, and in the conclusions of his monograph he makes an interesting reflection on the impact the expedition had on Malaspina's thought: «The seed from Newton and Smith in his thought resisted experimentation; questioning the idea of progress or the cyclical view of the history of empires represented an enrichment of his research, and the awareness that the legality in human makeup perhaps is not mechanical, but rather historic» (p. 396).

14 Malaspina (1991, pp. 145-147). On the influence of Newton and physics in Malaspina, see Pimentel (1998, pp. 143-162). 
Malaspina, in his diagnosis of the problems of Spanish America, explicitly adopted a comparative approach regarding the English and French empires, and stressed the extractive element of the Hispanic institutional framework - referred to by Acemoglu et al. (2001, p. 1376) - which revealed four main aspects: (a) the predominance of the spirit of conquest; (b) the clash of interests between Indians, Creoles and European Spaniards, those of the latter being pre-eminent; (c) the obsession with precious metals; and (d) the monopolistic and protectionist practices, of a mercantilist type, which had been ignored by Juan and Ulloa. This analysis confirmed for him that the Spanish empire was not just threatened by European powers, but also by an obsolete socio-economic system, which ruled in its interior.

First, if we compare the Spanish colonies with the English and French ones, he stated that the Spanish, as pioneers, had «too much room and too many opportunities to give rein to their greed and bravery»; on the other hand, other Europeans found the scene more limited and had to be content with being farmers or traders (Malaspina 1991, p. 148). The Spanish conqueror had been guided in particular to dominate and establish his laws; in this manner he contributed more to destruction, both of the newly discovered lands and those of his own homeland. On the contrary, English and French farmers and traders, although they started at a disadvantage in the colonial races, adapted and sought «intrinsic advantages in the land, trade and their own safety» (Malaspina 1991, p. 149). To sum up, traders and farmers «own, improve and defend»; on the other hand, the conqueror "captured, destroyed and moved on» (p. 150) ${ }^{15}$.

Second, Malaspina, as though it were a Newtonian principle, stated that the interests of Indians, Creoles and Spanish Europeans were «in continuous movement colliding with each other and this caused through a constant reaction the true weakening of everything» (Malaspina 1991, p. 156). The Indians were compelled to work in agriculture and the mines to support the basic necessities, recreation and fancies of the Europeans (Malaspina 1991, p. 157); the Spanish Europeans regarded the lands of Spanish America as an «acquired conquest» for their sole benefit (p. 161); and the Creoles believed their due was not only "the right of citizenship, but also the great relief promoted by legislation in favour of those settling in Spanish America» (p. 161). In one of the memoirs he wrote after his voyages, referring to the provinces of Río de la Plata, he stated that the interests of the Creoles could not be harmed:

«I will not conceal from the rectitude of government that despite the colonies owing, as far as trade is concerned, to be useful and pay their

15 On his return from his travels in Spanish America, he continued to criticise the spirit of conquest. Thus, for example, regarding the reign of Philip II he pointed out: "The Monarchy was similar to the miner: he gave up an object of average wealth for an imaginary discovery of others which were inexhaustible» (Malaspina 1995, p. 77). He also criticised England when her actions were inadequate, as in the case of the colonisation of Australia (Malaspina 1995, pp. 217-247). 
taxes to the motherland, they should not however lose the right to use their funds in products from their territories, the latter being the only right they still have when in importing and exchanging they have to pay taxes. Without this right they will be condemned to permanent poverty as the way they have to expand their industry or to use or form their own funds becomes ever-narrower» ${ }^{16}$.

Third, and closely related to what has just been mentioned, Malaspina highlighted the obsession of European Spaniards with the extraction of precious metals, which led them to destroy the economy and to forced labour for the Indians. Even more, he claimed that the constitution of a society should have as its aim its own welfare and defence, yet the system that had been installed in the Spanish colonies, far from preserving order and justice, was based on "the extra charge of the government authority", with a costly military defence system, problems to collect taxes, a surfeit of public servants and various regulations to control private activity (Malaspina 1991, pp. 160-170). The obsession over precious metals and associating them with wealth had also been a disaster for the Iberian Peninsula. Thus, by applying the quantitative theory of money, Malaspina stated that the abundance of precious metals in the Peninsula had ruined money values: «Spain no longer saw any greater amount of silver than that for which she became a creditor or by the fruits of her labours or by manufacturing» (Malaspina 1991, p. 174).

Fourth, all the monopolistic and protectionist methods that the Monarchy had used to prevent the removal of precious metals and protect their interests had petered out in smuggling, impoverishing the productive sectors through abandonment, misuse of human resources and the public purse, and to enrichment for foreigners. Spain had invested enormous amounts of public money in conquering territories and had provided public servants, the religious and the military, all of which in the end had ended in the pockets of foreigners: «the discovery of America had no happy ending for Europe except that of opening up a new landing place for its natural produce and devices and for its industry» (Malaspina 1991, pp. 179-180).

However, the Italian sailor not only criticised the measures to restrict trade, but also those who set up factories protected by the State. Thus, the eighth axiom said: "Manufactures, if violent, far from being a benefit to national prosperity, destroy it» (Malaspina 1991, p. 190). A protected manufacture was costly for the State, it was not based on the skill of its operators, and gave rise to high wages and high prices for products. In turn,

16 Malaspina (1995: 61). In another memoir said: «It is difficult to balance the prosperity of the mother country and the colonies when their interests are totally opposed, and if one tends towards the crown monopoly, the exclusive and sole circulation of its funds, just as the other is inclined in favour of freedom, competition and use of one's riches» (Malaspina 1995, p. 39). 
this encouraged smuggling and dissent among the Native Americans, who had to consume expensive products which did not exactly meet their requirements. Thus, he said in conclusion: «it should not appear paradoxical that with no industry a nation is poor and almost defenceless, and that one of the factors that make Spain poor and almost defenceless is the present progress of its industry just because it is violent» (Malaspina 1991, p. 194). However, also, an enormous number of regulations had also brought about numbers of public employees and had fed idleness. Thus, in axiom nine he said: "a job or a marriage in Spanish America decides the fate of any Spaniard, so he does not need either education or hard work» (Malaspina 1991, p. 196).

In view of this analysis of the Spanish colonial system, Malaspina proposed reverting the disastrous situation and entrusting it to a joint solution for the whole Empire, based upon greater economic freedom and the use of economic calculation in those decisions taken and involving public money. He insisted that the solid basis of wealth was not found in precious metals, but rather, the development of productive sectors without State support, which had led to the establishment of manufactures by the State in a "violent» way ${ }^{17}$. In addition, he proposed considering colonies as equals to the Crown's peninsular territories and not merely a source of income and raw materials.

\subsection{Alexander von Humboldt}

As we have already said, Humboldt visited New Spain at the beginning of the $19^{\text {th }}$ century, when the measures designed in the reigns of Ferdinand VI and Charles III (administrative and fiscal reforms, trade liberalisation in the heart of the Empire, etc.) finally started to show results. In this sense, he differed from Juan, Ulloa and Malaspina in that his view was more favourable, at least in certain aspects. On the one hand, he gave a detailed description of the productive sectors and the natural and population base of the territory visited - something the other travellers did not do - offering a panoramic view full of darkness and light. Although there had been some important advances (in questions of demographics, agrarian, scientificcultural matters, etc.), a general idea took root of an enormous undeveloped potential, especially when seen in the light of a comparison with the United States. Moreover, Humboldt went into detail about the persistence of old institutional problems already mentioned by his predecessors, with particular emphasis on the question of social inequality, but he also

17 After the expedition Malaspina insisted on the need for «a balanced tax system», «a pleasant police force which is needed by the colony» and «liberty enough to be able to work in anything not against the law, in which the vassal does not need to seek authorization for everything, rather the administration should make sure [...] they are not infringing the law» (Malaspina 1995, p. 198). 
commented that some improvements had been made. Let us consider both points, beginning with the already mentioned description of the socio-economic structure of New Spain.

As Juan and Ulloa had done for Peru, Humboldt underlined the formidable allocation of natural resources in the Viceroyalty ${ }^{18}$ : a considerable mineral wealth which went beyond the precious metals; the high fertility of a large part of the territory, where there was room for a wide variety of products; abundant land for cultivation, which had not yet been ploughed up; or the favourable geographical location for international trade ${ }^{19}$. This rich natural base had enabled a clear economic growth, albeit rather less than its potential due to a deficient institutional framework. In this sense the reference for comparison was his much admired United States, with a liberal government, not a despotic one, and where the population and aggregate production grew much more rapidly (Humboldt 1991, p. 6). That was, Humboldt placed more emphasis than Juan or Ulloa on the idea of huge possibilities wasted, not so much because the State did not carry out some of its functions properly in accordance with Smith's idea, but particularly through too much government intervention, which restricted economic freedom and distorted market forces in line with the comments of Malaspina. Likewise, in Humboldt's approach there was an underlining element of Smith's regarding the influence of different institutional patterns when attempting to explain the economic success of British colonies in North America compared with the poor performance of the Spanish and Portuguese (Humboldt 1991, p. 207).

Economic and social progress in New Spain was undoubted placing it at the head of Spanish America (Humboldt 1991, p. 1). There was a notable increase in population thanks to "the increase in interior prosperity», and this in turn was reflected in general increases in tax receipts (Humboldt 1991, p. 50). Moreover, in the specific case of agricultural produce, the best indicator of its improvement was in the increase in tithes (Humboldt 1991, pp. 43, 237). Moreover, there were advanced scientific establishments such as the School of Mining and modern science was cultivated, there were cities elegantly laid out and with solid buildings, the intellectual elites developed an intense cultural activity, some of the hydraulic works were admirable (such as the drainage canals near the capital), or there was an efficient postal system, all of which could stand comparison with the best of Europe (Humboldt 1991, pp. 4, 69, 79-81, 118-120, 139).

18 Weiner (2012, pp. 284-285) considers that Humboldt's influential Ensayo inculcated in Mexicans and foreigners the idea of totally overvalued natural riches.

19 Humboldt (1991, pp. 4, 29, 262-263, 331-335, 389-390). In a certain way Humboldt seems to point out that wealth from the land slowed up the progress of civilisation; that is, only need aroused hard work and skill, and the fact that a small piece of land was enough to feed a relatively large group of people, as in the case of the banana, had its effect in a low level of effort (Humboldt 1991, pp. 243-246). See Boianovsky (2013, p. 68). 
However, the reality of these achievements was a long way from what was really possible. Demographic growth was not only below that of the United States, but even that of Russia, where the physical conditions and climate were rather poorer (Humboldt 1991, pp. 40-41, 43). Moreover, the population was concentrated in the centre of the kingdom, leaving the most fertile land and that closer to the sea almost uninhabited (Humboldt 1991, p. 39). As for the level of development of the productive sectors, it was a long way behind its potential, a reflection, in one way or another, of bad government.

Agriculture was, for Humboldt, the only true source of national wealth, not large amounts of precious metals ${ }^{20}$. Moreover, against the most widespread opinion, it was also the main economic activity in Mexico, not mining which, furthermore, far from spoiling cultivation of the land - as had long been argued - had favoured it by attracting settlers to previously unpopulated areas (Humboldt 1991, p. 238). Following Jovellanos, Humboldt affirmed that agriculture had progressed in spite of the numerous obstacles hindering its development. These, to a great extent, were similar to those facing the primary sector in the Iberian Peninsula (concentration of property, absenteeism, primogeniture, extreme poverty among native farm workers, difficulties for internal trade, etc.) (Humboldt 1991, pp. 177, 318). Nevertheless, it was clear that much more progress could have been made. For example, cultivating produce such as oats, rice or fruit trees was obviously neglected, whereas that of olive trees, vines, mulberry trees, hemp or flax had been forbidden more or less openly by the Spanish government (Humboldt 1991, pp. 265, 274-275, 277). Similarly, other crops that provided raw materials for manufactured products and, which could perform very well in the coastal area - such as sugar cane, cotton, vanilla, cocoa or indigo - were underused, and their great development possibilities untouched, whereas tobacco growing had been restricted by the State monopoly (Humboldt 1991, pp. 286-298). Pearl fishing was also ignored as was breeding cochineal insects - an insect which was very important for dying in European manufacturing (Humboldt 1991, pp. 304, 310). Moreover, further opportunities for enrichment were overlooked by not engaging in whale hunting, an activity dominated by English and American English (Humboldt 1991, p. 312). Moreover, as a final comment, Humboldt complained about the destruction of wooded areas in the great inland meseta - «settlers have destroyed but not planted» - and of the artificial draining of wetlands, thus contributing to a bare, arid area rather like the Castilian plains (Humboldt 1991, pp. 28-29, 116-117, 139).

${ }^{20}$ Humboldt (1991, pp. 316, 445). Cervantes (2012, p. 156), in the same as Ortega y Medina (1991), considered that, in his view of the agricultural sector, Humboldt started out carrying the theoretical baggage of physiocracy and English political economy. However, Labastida (2004, p. 30n) does not believe that Humboldt can be regarded as a physiocrat; he cites Smith and Malthus, but not physiocrats. 
Mining activity, with little diversification, left a great deal to be desired. In the case of rich silver mines, despite its production having grown very much of late, it is oddly not much more important (Humboldt 1991, pp. 385, 398). The explanation lay in a group of factors: technological backwardness, bad economics in the administration, lack of information on the geological structure of the seams (perhaps because the workings were totally in private hands and the government had no powers to intervene), excessive taxes, which encouraged fraud, a monopoly in mercury distribution, or malpractice in exploiting (waste of gunpowder, mineral transportation on men's backs, lack of communication between the different plans for working the same mine, etc.) (Humboldt 1991, pp. 337, 365-371, 382, 401). Anything which was not precious metal - copper, tin, iron, lead or mercury - was pretty well ignored, and in a large number of sites work had not even begun (Humboldt 1991, pp. 389, 402).

In manufacturing the situation was bleak: they were even more backward and scarce than in Spain itself, so they could offer no competition for manufactured goods from the Iberian Peninsula nor affect the interests of monopolists in Spain (Humboldt 1991, pp. 449-450). Thus, for example, there was no manufacturing of flax, hemp or paper, and practically no silk (Humboldt 1991, pp. 452-453). Moreover, china, hats and glass - previously booming - had declined, and tobacco and gunpowder were royal rights, and so their production was limited and often smuggled (Humboldt 1991, pp. 453-454). Luxury products such as furniture, which could make use of raw material from the territory itself, and had great potential for exporting to Europe, had still not been developed (Humboldt 1991, p. 461). Perhaps only silver and coins were activities of some importance, albeit the latter were made with very imperfect methods (Humboldt 1991, p. 457). Moreover, in the case of cotton, the manufacturing places (obrajes) in Querétaro surprised Humboldt by their technical backwardness and the bad working conditions, which were unhealthy and oppressive (Humboldt 1991, p. 451).

As far as internal trade was concerned, it was badly hampered by the lack of navigable rivers and canals, but especially by the bad state of the roads, where they had not been fit for traffic for the transporting of goods and the use of mules was preferred. In particularly bad condition were the roads crossing the inner meseta in the direction of the coasts, and although some serious attempts appeared to be in progress to improve them, the problem was that ministers took up and then abandoned projects quite frivolously (Humboldt 1991, pp. 27, 462-463, 470). The aim to link the two oceans via a canal which was decisive for the country and would bring closer the products from China to Europe, seemed to be very advanced, with nine possible geographical areas already analysed. However, no plan had been drawn up (Humboldt 1991, pp. 7-8).

Finally, in foreign trade the advantages of the geographical setting were not exploited and the ports languished for lack of enough custom (Humboldt 
1991, p. 101). On the west coast, trade with Asia and other ports in Spanish America in the Pacific (such as Lima and Guayaquil) was extremely scarce, hardly ten boats a year in Acapulco. The reason for this was largely the monopoly of the Philippines Company (galleon from Manila) and the difficulty to navigate towards the coasts of Peru (strong currents, frequent storms in winter, etc.) (Humboldt 1991, p. 482). However, neither would they have been able to take economic advantage of possessions like the Mariana Islands or the good position of some American ports for taking part in the lucrative business of fishing for the sperm whale or hunting otters (Humboldt 1991, pp. 493-495). Moreover, if we look at trade with Europe from the east coast, the sole natural port - not a good one - was Veracruz, and that acted as a limiting factor for marine traffic (Humboldt 1991, p. 471). However, worst of all was the fact that Spain wanted exclusive contracts, which they still tried to impose on exchanges with their American colonies. Owing to this, smuggling, an important activity, continued; albeit the relative freeing of colonial trade which Charles III had implemented had brought some increased prosperity, it had not been enough. In fact, when a naval war prevented communication with Spain trade in the colonies was much livelier (Humboldt 1991, p. 496). In any case, the heavy trade deficit that New Spain had - offset by the prodigious exporting of precious metals - was completely "artificial» and only explained by the many restrictions and obstacles of all types that the Spanish government put in the way of agriculture, manufacturing and trade (Humboldt 1991, p. 505).

This poor showing in the general economy by New Spain regarding its potential and the United States stemmed, as we have said, from a deficient institutional structure. Not so much, as indicated by Juan and Ulloa for the Viceroyalty of Peru, by a widespread culture of corruption and easy money which marred the working of internal justice and government, but by questions of bad institutional design and excessive intervention that stifled free initiative through restrictions and monopolies, just as Malaspina had pointed out. Humboldt insisted that the State had not performed its basic functions regarding the construction of basic infrastructures (roads, ports, canals) which would favour trade and offset the physical limitations, such as the difficult relief, lack of navigable rivers, lack of natural ports on the east coast or the arid interior.

However, Humboldt considered - in tune with Engerman and Sokoloff (1997, pp. 289-291) - that the big institutional problem in New Spain, a potentially explosive one, lay in the profound social inequality of fortunes and civilisation, in such a way that wealth and a good education of a few was in contrast to poverty, lack of clothing and ignorance among the majority, in a rigid system of seven racial groups with privileges accruing to the whites (Humboldt 1991, pp. 69-70). Particularly bad was the situation of the large Indian population, which lived wretched lives, deprived of important rights, and also being lazy by nature (Humboldt 1991, pp. 47, 69-70). 
Humboldt made it clear that if there were no significant improvement in the Indians' situation - in line with proposals of the Bishop of Michoacán, Antonio de San Miguel - there could be no real socio-economic progress, and criticised the government's strategy of encouraging ill will between some racial groups and others (whose conflicting interests had already been noted by Malaspina), and this gave rise to mutual hatred, envy and bad feeling, which in itself was a result of strong social inequality (Humboldt 1991, pp. 70-74, 94-96, 566).

Consequently, unlike other travellers, Humboldt did not put so much stress on the extractive nature of Spanish colonial institutions - although, as we have seen, he often referred to it implicitly when describing the different productive sectors - but in the question of the great inequality. However, curiously, he paused to analyse the public finance sphere - to which other visitors had paid scant attention - as a clear example of poor public management, and one led by the interests of Spanish government. Fiscal administration was inefficient and tax collection was slow and very onerous ${ }^{21}$. The inhabitants of New Spain paid a third less in taxes than those in the Iberian Peninsula, but a very important part of their payments was sent to the Royal Treasury in Madrid (Mexico contributed to Spain more than two-thirds of the net total from the colonies) (Humboldt 1991, pp. 551-552). Defence expenditure accounted for nearly a quarter of resources, with an army of 32,000 men - hardly 10,000 disciplined - in spite of there being no serious outside threats and having a territorial configuration, which made its defence easier, especially on the Atlantic side (Humboldt 1991, pp. 553, 556, 563). Nonetheless, on the Northern frontier a costly, never-ending war was waged against the braves (Apaches, Comanches, etc.), which had led to the usual sale of ranks (Humboldt 1991, p. 562). What is more, in those outposts of the Empire - where the system of missions and presidios still prevailed — there was no civil society, and the "hapless Indian» was caught «between a corporal or a missionary» (Humboldt 1991, p. 199).

However, despite all his criticisms, Humboldt also noticed significant progress and improvements in the institutional area, as a consequence of the implementation of the Bourbon reforms. Thus, he had a more qualified, positive vision than that of Juan, Ulloa and Malaspina and it helped to rehabilitate the global image of the colonies, compared with the very negative portrait offered by foreign writers such as Raynal or Robertson ${ }^{22}$. For example, first he praised the work of the most recent viceroys and the general integrity of the governors (intendentes), who passed on the idea that the Bourbon reforms had meant a clear advance towards the establishment of a minimally effective State, with a colonial administration that was more

21 Humboldt (1991, p. 545). On Book VI of the Ensayo, see Marichal (2012).

22 On how Humboldt renovated the European image of Mexico and Spanish America, see Minguet (2001). 
efficient and controlled, along the lines suggested by Hough and Grier (2015, pp. 184-202). In this sense, the introduction of the system of governors (intendentes) had been a good idea on paper, though the territorial division very uneven - did not work because there was no relationship between the population and the surface of each governorship (intendencia). As a result, in some of the enormous territorial areas of some governorships it was difficult to exercise authority. Consequently, administrative vices appeared; and there was still a shortage of basic statistical and geographical information to make possible the application of «the simplest principles of political arithmetic» (Humboldt 1991, pp. 106-107).

Second, although Humboldt denounced ill treatment of Indians, saving particular criticism for the Conquest period, he did not glorify the preColumbus period and praised the advances made during the reign of Charles III: for instance, the Indians lived better than the farm workers of Courland, Russia or Northern Germany; they were in any case free workers, even in the mines, where they were better paid than in Europe (in Mexico the mita did not exist and there were scarcely any black slaves); they were exempt from indirect taxes; and were beginning to enjoy the benefits granted by mild, humane laws thanks in general to the work of mayors or governors (intendentes) (Humboldt 1991, pp. 48-49, 67-70, 86).

Third, Humboldt appreciated the fact that the Viceroyalties were not in principle colonies stricto senso like those exploited by England and Holland, but far-off provinces, which were a part of the Spanish empire like other peninsular regions, making up a sort of confederation of states. The problem was that in practice their inhabitants were still «deprived of many important rights in their relations with the Old World", and that, despite the fact that these territories had been run more liberally in the last 20 years (Humboldt 1991, pp. 450, 539). The political regime had become more Royalist and had gradually been moving Creoles from government posts, creating resentment among them (Humboldt 1991, p. 76).

In any case, in spite of the Bourbon reforms and progress observed, Humboldt appeared to propose implicitly the independence of Mexico as the only sure way of progressing, from a liberal government, which would set the necessary reforms going. This could be done, on the one hand, by perfecting social institutions and guaranteeing equality before the law for citizens, and, on the other, giving free rein to agriculture, mining, manufacturing and trade. In this fashion a full and more balanced development of all the productive services would develop (Humboldt 1991, pp. 496, 505, 551, 553, 560).

\section{CONCLUSION}

The travellers analysed in this work detected the main institutional problems of the Spanish colonial system in America between the mid-18 
century and early $19^{\text {th }}$ century. Such problems, as Smith pointed out, were behind the worse economic performance of Spanish colonies, when compared with the English ones. However, what is more, as we have seen, these problems also coincided essentially with those highlighted nowadays by some of the most important scholars of the role played by colonial institutions in long-term economic development: the strong extractive nature of institutions, profound social inequality, or the deficiencies in a public administration which was not very efficient and unable to deal with basic tasks. It is true that the Bourbon reforms began to introduce improvements - as reflected in Humboldt's writing - but it was perhaps too late.

The four travellers aimed to influence economic policy questions affecting "the sources of prosperity" of Spanish territories in America. However, they were not listened to. Despite the analysis they made as a result of what they had learned on their voyages, they had not the slightest influence on Spanish political media. The harsh criticisms of Juan and Ulloa regarding the corruption of public servants and the ecclesiastics - excepting the Jesuits alongside their distrust of sailors with no expertise in economic matters, who also defended private interests, gave rise to their reflections and proposals not being taken into account by Ensenada (Juan and de Ulloa 1985, I, pp. 386-397). Moreover, Malaspina returned from America with the image of being «a new Cook», but his standoff with Godoy led him first of all to prison and then into exile. Consequently - according to Humboldt (1991, p. 217) - his works were «buried in the archives». Finally, Humboldt's influence, rather than on those deputies in the Cortes of Cadiz, impacted on those Creoles who had been in favour of emancipation (Weiner 2015, pp. 142-145) or on those writers such as Blanco White, who considered that the colonies were not yet ready for independence and proposed that these territories should remain under Spanish control with profound socio-economic reforms (Perdices de Blas and RamosGorostiza 2014).

All in all, the waste paper basket received the valuable analysis of authors who had been there and had made on-the-spot studies both of the wealth of those lands, still largely to be developed, and the institutional framework in which economic activities took place. Juan and Ulloa stressed three functions not performed by the State (administration of justice, defence against attack from foreign enemies and basic infrastructures), whereas Malaspina and Humboldt underlined the monopolistic and protectionist practices of a mercantilist type. As a result of his observations everyone reached the conclusion that the problem of Spanish-American colonies was not exclusively an outside matter (the possible effect of the independence of English colonies from 1776 onwards or the aggressiveness of other European colonial powers, particularly in the South Pacific, considered a Spanish ocean up to the $18^{\text {th }}$ century), but, also and particularly, internal causes related to the organisation of the empire in accordance with obsolete economic guidelines which were an obstacle to economic growth. All of this 
was in spite of the fact that he gave a positive valuation to the reforms made during the reigns of Ferdinand VI and Charles III.

The analysis made by the four travellers loses nothing in merit if we compare it with the one made by the final generation of the Enlightenment, represented by Francisco Cabarrús, Valentín de Foronda and Gaspar de Jovellanos, or by the early liberals such as Álvaro Flórez Estrada. These authors - unlike the travellers studied here or Blanco White, who read and extended the work of Humboldt - concentrated on commercial topics following the trail of Campomanes, or else they hesitated like Valentín de Foronda. The latter, in his Disertación sobre la nueva Compañía de Indias Orientales (Dissertation on the New East India Company) (1784), initially defended this firm's privileges; later on in Cartas sobre los asuntos más exquisitos de economía politica y sobre las leyes criminales (Letters on the most exquisite matters of political economy and criminal laws) (1788-1791), he criticised the harmful effects stemming from the granting of exclusive rights; and finally, in his Carta sobre lo que debe hacer un príncipe que tenga colonias a gran distancia (Letter on what a prince with distant colonies should do) (1803) even proposed selling Spanish colonies in America (Perdices de Blas and Reeder 2003, pp. 191-192). That is, one receives the impression that Spanish economists were not so aware of what was really going on in America as Juan, Ulloa, Malaspina and Humboldt, who, with all the limitations mentioned in this work, at least saw with their own eyes the real state of the Spanish empire and the problems awaiting solution, those mainly related to an inadequate institutional framework.

\section{REFERENCES}

Acemoglu, D.; Johnson, S., and Robinson, J. A. (2001): «The Colonial Origins of Comparative Development: An Empirical Investigation». American Economic Review 91 (5), pp. 1369-1401.

Acemoglu, D.; Johnson, S., and Robinson, J. A. (2002): «Reversal of Fortune: Geography and Institutions in the Making of the Modern World Income Distribution». Quarterly Journal of Economics, 117 (4), pp. 1231-1294.

Artola, M. (1969): «América en el Pensamiento español del siglo XVIII». Revista de Indias, 117 , pp. 51-77.

Boianovsky, M. (2013): "Humboldt and the Economists on Natural Resources, Institutions and Underdevelopment». European Journal of the History of Economic Thought, 20 (1), pp. 58-88.

Brann, E. R. (1954): The Political Ideas of Alexander von Humboldt: A Brief Preliminary Study. Madison: Little Printing.

Cervantes, F. J. (2012): "La Agricultura en el Ensayo político: Sobre el Método y la Interpretación», in J. E. Covarrubias, and M. Souto (eds), Economía, Ciencia y Política: Estudios Sobre Alexander von Humboldt a 200 Años del «Ensayo Político Sobre el Reino de la Nueva España». México: Instituto Mora-UNAM-IIH, pp. 139-161.

De Solano, F. (1999): La Pasión de Reformar: Antonio de Ulloa, Marino y Científico, 17161795. Cádiz-Sevilla: Universidad de Cádiz-Escuela de Estudios Hispanoamericanos. 
DE UlLOA, B. (1992): Restablecimiento de las fábricas y comercio español. Madrid: Antoni Bosch.

DE la Sota, J. (1994): «La América posible», in B. Sáiz (ed.), Alejandro Malaspina. La América Imposible. Madrid: Compañía Literaria, pp. 11-17.

Engerman, S. L., and Sokoloff, K. L. (1997): «Factor Endowments, Institutions and Differential Paths of Growth among New World Economies», in S. Haber (ed.), How Latin America Fell Behind. Stanford: Stanford University Press, pp. 260-304.

Ezquerra, R. (1962): «La Crítica Española de la Situación de América en el Siglo XVIII». Revista de Indias, 87-88, pp. 159-283.

Hough, J. F., and Grier, R. (2015): The Long Process of Development. Building Markets and States in Pre-Industrial England, Spain, and Their Colonies. New York: Cambridge University Press.

Humboldt, A. V. (1991): Ensayo político sobre el reino de la Nueva España. México: Porrúa.

JuAn, J., and De UlloA, A. (1985): Las «Noticias secretas de América» de Jorge Juan y Antonio de Ulloa (1735-1745), 2 vols. Madrid: CSIC-Instituto Gonzalo Fernández de Oviedo.

Labastida, J. (2004): «Humboldt en la Nueva España», in R. Erickson, M. A. Font, and B. Schwartz (eds.), Alexander von Humboldt: From the Americas to the Cosmos. Nueva York: The Bildner Center for Western Hemisphere Studies, pp. 25-39.

Llombart, V. (1992): Campomanes, economista y politico de Carlos III. Madrid: Alianza.

Losada, M., and Varela, C. (1995): Actas del II Centenario de Don Antonio de Ulloa. Sevilla: CSIC-Escuela de Estudios Hispanoamericanos.

Malaspina, A. (1991): Los "Axiomas políticos sobre la América» de Alejandro Malaspina. Madrid: Theatrum Naturae.

Malaspina, A. (1995): Expedición Malaspina 1789-1794. Tomo VII: Descripciones y reflexiones políticas. Madrid: Ministerio de Defensa-Museo Naval-Lunwerg Editores.

Marichal, C. (2012): "Alexander von Humboldt y sus Reflexiones Sobre la Real Hacienda de la Nueva España: Notas Sobre el Libro Sexto del Ensayo político», in J. E. Covarrubias, and M. Souto (eds), Economía, Ciencia y Política: Estudios Sobre Alexander von Humboldt a 200 años del "Ensayo Político Sobre el Reino de la Nueva España». México: Instituto Mora-UNAM-IIH, pp. 247-260.

Minguet, C. (2001): «Una Nueva Imagen de la América Española: la obra de Alejandro de Humboldt (1805-1850)», in L. Zea, and H. Taboada (eds), Humboldt y la Modernidad. México: IPGH/FCE, pp. 7-24.

Newland, C., and Waissbein, D. (1984): "Una Nota Sobre Adam Smith, Ulloa y la Economía de Buenos Aires». Revista de Historia Económica, 2 (1), pp. 161-167.

Ortega Y Medida, J. (1991): «Estudio Preliminar», in A. von Humboldt (ed.), Ensayo Político Sobre el Reino de la Nueva España. México: Porrúa, pp. I-CLXXX.

Paquette, G. B. (2008): Enlightenment, Governance, and Reform in Spain and its Empire, 1759-1808. Basingstoke and New York: Palgrave Macmillan.

Perdices De Blas, L. (1996): La Economía Política de la Decadencia de Castilla en el siglo XVII. Madrid: Síntesis.

Perdices De Blas, L., and Ramos Gorostiza, J. L. (2014): «Blanco White, Spanish America, and Economic Affairs: The Slave Trade and Colonial Trade». History of Political Economy 46 (4), pp. 573-608.

Perdices De Blas, L., and Reeder, J. (2003): Diccionario de Pensamiento Económico en España (1500-2000). Madrid: Síntesis-Fundación ICO. 
Pimentel, J. (1998): La Física de la Monarquía. Ciencia y Política en el Pensamiento Colonial de Alejandro Malaspina (1754-1810). Madrid: Doce Calles.

Sмiтн, A. (1987): Investigación Sobre la Naturaleza y Causas de la Riqueza de las Naciones. 2 vols Barcelona: Oikos-Tau.

Soler, E. (2002): Viajes de Jorge Juan y Santacilia: Ciencia y Política en la España del siglo XVIII. Barcelona: Ediciones B.

Vericat, J. (1994): «Fuentes del Pensamiento Socio-político de Malaspina», in M. Palau, and A. Orozco (eds), Malaspina'92: I Jornadas Internacionales. Cádiz: Real Academia Hispano-Americana, pp. 14-18.

Weiner, R. (2012): «La riqueza legendaria de México: lectura selectiva del legado del Ensayo político de Humboldt», in J. E. Covarrubias, and M. Souto (eds), Economía, ciencia y política: estudios sobre Alexander von Humboldt a 200 años del «Ensayo político sobre el reino de la Nueva España». México: Instituto Mora-UNAM-IIH, pp. 261-289.

WeInER, R. (2015): «México and Central America», in V. Barnett (ed.), Routledge Handbook of the History of Global Economic Thought. Londres: Routledge, pp. 140-148. 